\title{
THE USE OF COMPLEMENTARY AND ALTERNATIVE MEDICINE (CAM) AMONG ITALIAN CHILDREN: A CROSS- SECTIONAL SURVEY
}

\section{BACKGROUND}

The topic of Complementary and Alternative Medicine (CAM) has been widely discussed in the scientific literature, including two highly-cited editorials that appeared in NEJM ${ }^{1}$ and JAMA ${ }^{2}$ in 1998. These articles agreed on a fundamental point, that is that the only accepted form of medicine should be based on evidence. Since then, many authors have tried to define what is CAM. A positive definition, describing CAM by what it is, rather than by what it is not, has been proposed by Ernst et al.: CAM is any "diagnosis, treatment and/or prevention which complements mainstream medicine by contributing to a common whole, by satisfying a demand not met by orthodoxy or by diversifying the conceptual frameworks of medicine". ${ }^{3}$

Surveys from several European countries suggest a European-wide increase in the use of CAM during the last decades. ${ }^{4}$ The prevalence of the use of CAM among adults in European countries, varies from $6-49 \%$ according to different studies $5,6,7,8,9,10$. Data for Italy is contradictory. According to a national survey, in 2005 at least $13.6 \%$ of population have used CAM during the last three years ${ }^{11}$, but a study conducted in Turin in 2008 estimates a prevalence of use of $43 \%$ in paediatric age during the previous year ${ }^{12}$. This figure is consistent with other studies which have underlined that approximately $20 \%$ to $40 \%$ of healthy children seen in outpatient paediatric clinics ${ }^{13}, 14,15$ and more than $50 \%$ of children with chronic, recurrent, and incurable conditions use CAM, almost always in addition or conjunction with mainstream care ${ }^{16}$.

Children's health is not self-determined and depends on their parent's' choice. Considering the spread of the CAM use and the lack of recent studies estimating prevalence of CAM use in Italy, we believe in the importance of better understanding the amount and modality of CAM use in the paediatric population in order to identify any possible risk and health problem.

\section{OBJECTIVE}

The aim of this study is to examine the prevalence and modalities of complementary and alternative medicine (CAM) use in children living in Novara, a 100,000 inhabitants industrial city in the North of Italy, in order to understand better the phenomenon and identify any possible related public health risk.

In the study we will investigate the characteristic related to the CAM use and the relations between CAM use and parents' propensity to use conventional medicine interventions, such as vaccinations.

Other aspects we will investigate are the paediatrician's knowledge about CAM and their attitude to CAM prescription. 
Following recommendations of European Parliament, adopted by the Italian Medical Association, for this study we considered nine CAM disciplines: Acupuncture, Phytotherapy, Ayurvedic Medicine, Anthroposophic Medicine, Homeopathy, Traditional Chinese Medicine, Homotoxicology, Osteopathy, Chiropractic.

We conducted a survey of parents of 2-14 years children in Novara, a city in the north of Italy, located between Milan and Turin. The total number of children from 2 to 14 years registered in files of the Local Health Unit (ASL) of Novara in January 2015 was 38320, of which 19587 were males and 18733 females. To complete the information we also surveyed all the General Paediatricians of the same area.

We conducted a cross-sectional population survey on a random sample of this population in April 2015. The sample size of 147 was calculated ${ }^{17}$ in order to estimate the use of CAM in that population with a $\alpha=0.05$ and a $\beta=0.80$, expecting the prevalence of CAM use derived from the Turin study ${ }^{12}$.

The sample of children 2-14 years was extracted in January 2015 from the database of the population registered in the ASL of Novara. Since a response rate of $25 \%$ was expected, we extracted 588 names and contacted them until we obtained 147 interviews.

We extracted addresses and telephone numbers of the children's parents and sent to them a presentation letter of the telephone interview. We administered the questionnaire during March and April 2015, through a Computer Aided Telephone Interview (CATI). All the phone calls were made by a single researcher (VS). We introduced all the questionnaires by a standard sentence, describing the study, informing parents about data protection and about the possibility to opt out from the study at any time.

We designed the questionnaire on the model of those already existing in Italian, especially considering the ones of Turin $2008^{12}$ and those from the south of Italy ${ }^{18}$, while taking into consideration the recommendations of scientific literature ${ }^{19}$. The questionnaire consisted of 24 items, both structured and open-ended. It included questions about the use of CAM in the whole child lifetime and in the last year; parent's attitudes toward medicines; child's health; sources of information about medicines; frequency of visits by paediatricians and demographic characteristics of responding parent and child. We first piloted the questionnaire with a convenient sample of 26 parents, whose answers were not included in the main study. We made minor modifications on the basis of the pilot-test to make it more understandable.

The main outcome measure of this study was parents' CAM use for their own child during their lifetime and in the preceding year.

We also conducted a survey of General Paediatricians of the ASL of Novara by sending questionnaires by e-mail to all paediatricians from the list of those practicing in the area (obtained from the local medical council) investigating their propensity to prescribe CAM and their training about it. We contacted a total of 36 paediatrician.

We tabulated children and parents population and paediatricians answers through Microsoft Excel 2011. We analysed socio-demographics, behavioural and clinical characteristics distribution between CAM users and non-CAM users by using Graph Pad 6. We tested binomial and categoric differences in study variables between the two groups using the chi square test (or Fisher test as appropriate). We tested differences in continuous variables between the two groups trough Student's t test. We used multivariable logistic analysis to test the relation between study variables and CAM use using Stata MP/13.1. We reported punctual estimations and their 95\% confidence interval. Threshold for significance was set at 0.05 .

\section{RESULTS}


We sampled 588 children, and randomly contacted parents until we reached the number of 154 people answering the phone. Some were not reachable by phone, some have never answered after 10 phone call; 7 refused the interview, with a response rate of $95.5 \%$ and a total of 147 interview in 147 different families. Of the interviewed parents, 104 (70.7\%) were mothers and 43 were fathers.

$48.3 \%$ of children living in Novara have been treated with CAM at least once during lifetime and $38.1 \%$ of them during the last year.

Table 1 represents the baseline characteristics of the children. $85.7 \%$ of children had less than 6 episodes of sickness in the last year, and more than half (53.7\%) experienced Ear, Nose and Throat (ENT) pathologies, such as otitis, rhinitis, cough, sore throat and mucus. All children of our sample, except one, received all the basic vaccinations covered by the health system (Diphtheria, Tetanus, Pertussis, Polio, Haemopihlus B, HBV, Measles, Mumps Parotitis, Rubella). During the last year parents visited the General Paediatrician once or twice in the $43.6 \%$ of cases and more than twice in the $44.2 \%$ of cases. Only the $26.5 \%$ went to a Private Paediatrician in the last year. The majority of children $(70.0 \%)$ never used medicaments chosen by parents, and $35.4 \%$ of them has been treated with medicaments suggested by others, different by doctors, such as pharmacists, herbalist, naturopathic and other healers.

Table 2 describes the characteristics related to the CAM-users and not CAM-users groups. Children treated with CAM were on average younger than those who do not use them (7.0 vs 8.0 years), and their main pathologies involve the ear, nose and throat apparatus; they were also more frequently treated with medicaments suggested by herbalists or pharmacist.

Table 3 presents parental characteristics according to CAM use. Parents who use CAM for their children were more likely to have a job and to have higher educational qualifications. It was found a negative association between parents' positive attitude towards CAM use and their propensity to vaccinations. No significant associations were found between CAM use and parents' socioeconomic status.

Table 4 describes the results of univariable and multivariable analysis. In the univariable analysis, the odds of CAM use increased if the child had an ENT disease (odds ratio [OR] 2.14; $95 \%$ confidence interval [95\% CI] 1.10-4.14) but this association disappeared in the multivariate analysis (OR 1.48, 95\% CI 0.69-3.18). An inverse association between a positive attitude towards vaccination and CAM use was noted in the univariable analysis (OR 0.34; 95\% CI 0.14-0.81) but was attenuated in the multivariable analysis (OR $0.40 ; 95 \%$ CI $0.15-1.03 ; \mathrm{p}=0.058$ ). If the treatment was suggested by nonmedics (e.g. pharmacists or herbalists) the odds of being treated with CAM increase in both univariable (OR 1.74; 95CI 1.24-2.46) and multivariable analyses (OR 1.66; 95\% CI 1.16-2.38). SES definition was based on parental education (high, at least one parent with university degree or higher; medium, at least one parent completed high school; low, both parents' completed middle or elementary school). Reference level was low SES.

Table 5 describes CAM use modalities. The only types of CAM used were herbal medicine $(73.2 \%)$ and homeopathy in (41.1\%). 50\% of users made a frequent use during the last year, $21.4 \%$ used them regularly. They are mostly used to treat pathologies of ear, nose and throat $(81.7 \%) .59 .2 \%$ is satisfied and $85.9 \%$ is willing to use CAM in future. 59.2\% of interviewed does not associate CAM to conventional medicine. $63.4 \%$ of parents believes that conventional medicine is more effective, while $12.7 \%$ finds CAM more effective. In case of CAM inefficacy $78.9 \%$ of users would move to conventional medicine, although $14.1 \%$ would try again with CAM. Only $66.2 \%$ of parents considers a medical prescription essential before starting a treatment with CAM; according to $21.1 \%$ the necessity of medical prescription depends on the pathology and $12.7 \%$ does not consider it necessary for any disease. Our research shows that $95.8 \%$ of users believe that CAM have no collateral effect, and $40.8 \%$ of them considers the avoidance of collateral effect as the main motivation to CAM use. The second main motivation is the doctor's prescription (29.6\%). Some parents $(8.5 \%)$ use CAM because it were already used by their parents, few of them (7.0\%) considerd CAM use a valid alternative to antibiotic in order to prevent antibiotic resistance. 
Table 6 shows results of paediatricians' interviews. All the 36 paediatricians practicing in the ASL of Novara have been contacted through their emails; 27 of them answered to the questionnaire. The questionnaire detected that $81.5 \%$ of paediatricians prescribes CAM $(100 \%$ and $40.9 \%$ of them prescribes respectively phytotherapy and homeopathy). In $90.1 \%$ cases, CAM has been associated to conventional therapy. Only $13.1 \%$ of paediatricians received specific education about CAM.

\section{DISCUSSION}

The prevalence of CAM users among children in Novara is higher than estimated in previous studies, and similar to Northern European countries. The type of diseases treated with CAM, parental socioeconomic status and the scepticism towards vaccination are similar to the data in literature.

Homeopathy and herbal medicine were the only types of CAM used by our study population. Because the study was powered to detect CAM use in general, it is possible that some less frequently used types of CAM were not detected. The large use of homeopathy and herbal medicine is probably partly due to the lower perception of risk of adverse effects that these treatments have compared to others, such as Traditional Chinese Medicine, Homotoxicology, or Chiropractic. A recent Cochrane review ${ }^{20}$ investigates the effectiveness and safety of homeopathic medicine to prevent and to cure acute respiratory tract infection in children. The authors concluded that adverse events were poorly reported, so conclusions about safety could not be drawn. It is noteworthy that $95.8 \%$ of users believe that CAM have no collateral effect and that only $13.1 \%$ of paediatricians received specific education about CAM.

There are two important risks connected to a large use of CAM use: i) there is little evidence about the safety of some CAM and their possible interactions with conventional medications ${ }^{21}$; ii) alternative medicine could be administered instead of effective medical care, for children with life-threatening conditions. In the current study, $14.1 \%$ of the parents declare that in case of CAM inefficacy they would try again with CAM.

This survey is representative for the paediatric population of Novara, given that the sample has been extracted random by the ASL files and in reason of the low number of refusals. Other cities in Northern Italy may have CAM prevalence similar to what we observed in our study. Although we do not have any means to control for inaccuracy of reporting, our study was conducted using CATI, a standardised interviewing instrument, and respondents were aware that the study was officially endorsed by the local health authority. Our study was limited by the relatively small sample size, as it was powered to estimate prevalence of CAM use - the main objective of this study. In this context, some attenuated associations found in multivariable analyses may be explained by lower power rather than lack of association, although the latter may be true. Larger studies are warranted to elucidate what attitudes and behaviours are related to CAM use.

Our research suggests that families in Novara have an interest in exploring the possibilities offered by alternative medicine, and they are willing to listen to the indications of their paediatricians. Paediatricians and other health professionals who provide child care have the responsibility to advise and counsel patients and families about safe, relevant, effective, and age-appropriate health services and therapies regardless of whether they are considered mainstream or CAM. Too often paediatricians do not feel comfortable discussing or recommending CAM therapies, due to a lack of education about the topic. They are not informed about their patient's CAM usage and they do not ask about it. Appropriate policies are warranted to enhance the way health professionals deal with CAM. The easy part is to routinely ask patients about CAM use and by recording their response ${ }^{22}$. The difficult part is to advise them responsibly, which requires an open mind and a non-judgmental attitude, as well as an up to date knowledge about which CAM interventions work and which do not, which treatments are safe and which are not. 


\section{ACKNOWLEDGEMENTS}

We are thankful to Dr Arabella Fontana for facilitating contacts with ASL, Dr Edoardo Moia for amministrative support.

\section{BIBLIOGRAPHY}

1. Angell M, Kassirer JP. Alternative Medicine - The Risks of Untested and Unregulated Remedies. N Engl J Med. 1998;339(12):839-841.

doi:10.1056/NEJM199809173391210

2. Fontanarosa PB, Lundberg GD. Alternative Medicine Meets Science. JAMA. 1998;280(18):1618. doi:10.1001/jama.280.18.1618

3. Ernst E, Resch KL, Mills S, et al. Complementary medicine - a definition. Br J Gen Pract. 1995;45(398):506.

4. Längler A, Zuzak TJ. Complementary and alternative medicine in paediatrics in daily practice-A European perspective, Complementary Therapies in Medicine, Volume 21, Supplement 1, 2013, Pages S26-S33 ISSN 0965-2299

5. Menniti-Ippolito F, Gargiulo L, Bologna E, Forcella E, Raschetti R. Use of unconventional medicine in Italy: a nation-wide survey. Eur J Clin Pharmacol. 2002;58(1):61-64. doi:10.1007/s00228-002-0435-8

6. Thomas K, Coleman P. Use of complementary or alternative medicine in a general population in Great Britain. Results from the National Omnibus survey. J Public Health (Bangkok). 2004;26(2):152-157. doi:10.1093/pubmed/fdh139

7. Hanssen B, Grimsgaard S, Launs $\varnothing$ L, Fønnebø V, Falkenberg T, Rasmussen NK. Use of complementary and alternative medicine in the Scandinavian countries. Scand $J$ Prim Health Care. 2005;23(1):57-62.

8. Bücker B, Groenewold M, Schoefer Y, Schäfer T. The Use of Complementary Alternative Medicine (CAM) in 1001 German Adults: Results of a Population-Based Telephone Survey. Das Gesundheitswes. 2008;70(08/09):e29-e36. doi:10.1055/s-2008-1081505

9. Schwarz S, Messerschmidt H, Völzke H, Hoffmann W, Lucht M, Dören M. Use of complementary medicinal therapies in West Pomerania: a population-based study. Climacteric. 2008;11(2):124-134. doi:10.1080/13697130801930674

10. Steinsbekk A, Rise MB, Aickin M. Cross-Cultural Comparison of Visitors to CAM Practitioners in the United States and Norway. J Altern Complement Med. 2009;15(11):1201-1207. doi:10.1089/acm.2009.0163

11. Roberti di Sarsina P, Iseppato I. Traditional and non-conventional medicines: the socio-anthropological and bioethical paradigms for person-centred medicine, the Italian context. EPMA J. 2011;2(4):439-449. doi:10.1007/s13167-011-0104-z 
12. Filippo M, Oliverio AC, Altomare F, et al. Review on the use of complementary medicine in pediatrics: an interregional study. Minerva Pediatr. 2013;65(4):361-370.

13. PITETTI, RAYMOND MD, MPH; SINGH, SONIA MD, MPH; HORNYAK, DEBRA MSN, CRNP; GARCIA, SYLVIA E. MD; HERR SM. Complementary and alternative medicine use in children. Paediatric Emergency Care. https://journals.lww.com/peconline/Abstract/2001/06000/Complementary_and_alternative_medicine_use_in.4.aspx . Published 2001.

14. Sawni-Sikand A, Schubiner H, Thomas RL. Use of Complementary/Alternative Therapies Among Children in Primary Care Paediatric s. Vol 2.

15. Loman DG. The use of complementary and alternative health care practices among children. J Pediatr Heal Care. 2003;17(2):58-63. doi:10.1067/mph.2003.29

16. Mccann LJ. Survey of paediatric complementary and alternative medicine use in health and chronic illness. Arch Dis Child. 2006;91:173-174. doi:10.1136/adc.2004.052514

17. Kim J, Seo BS. How to Calculate Sample Size and Why Special Report. 2013. doi:10.4055/cios.2013.5.3.235

18. Dolceamore TR, Altomare F, Zurlo F, Miniero R. Use of alternative-complementarymedicine (CAM) in Calabrian children. Ital J Pediatr. 2012;38:70. doi:10.1186/18247288-38-70

19. Toupin April K, Moher D, Stinson J, Byrne A, White M, Boon H, et al. Measurement properties of questionnaires assessing complementary and alternative medicine use in pediatrics: a systematic review. PloS One. 2012;7(6):e39611

20. Hawke K, van Driel ML, Buffington BJ, McGuire TM, King D. Homeopathic medicinal products for preventing and treating acute respiratory tract infections in children. Cochrane database Syst Rev. 2018;4(4):CD005974. doi:10.1002/14651858.CD005974.pub4

21. Posadzki P, Watson L, Ernst E. Herb-drug interactions: an overview of systematic reviews. Br J Clin Pharmacol. 2013;75(3):603-618. doi:10.1111/j.13652125.2012.04350.x

22. Ernst E. Complementary and alternative medicine for children: a good or a bad thing? Arch Dis Child. 2006;91(2):96-97. doi:10.1136/adc.2005.087163 


\begin{tabular}{|c|c|c|}
\hline \multicolumn{2}{|c|}{ Baseline characteristics of the children } & \multirow{2}{*}{$\begin{array}{c}\mathrm{N}(\%) \\
73(49.7 \%)\end{array}$} \\
\hline Sex & Female & \\
\hline & Male & $74(50.3 \%)$ \\
\hline $\begin{array}{l}\text { Total number of } \\
\text { children in the } \\
\text { family }\end{array}$ & $\mid \begin{array}{l}1 \\
2 \\
3 \text { or more }\end{array}$ & $\begin{array}{l}42(28.6 \%) \\
79(53.7 \%) \\
26(17.7 \%)\end{array}$ \\
\hline $\begin{array}{l}\text { episodes of } \\
\text { sickness in the last } \\
\text { year }\end{array}$ & $\begin{array}{l}\text { Less than } 6 \\
6 \text { or more }\end{array}$ & $\begin{array}{l}126(85.7 \%) \\
20(13,6 \%)\end{array}$ \\
\hline Main patologies & $\begin{array}{l}\text { ENT patologies } \\
\text { Other patologies }\end{array}$ & $\begin{array}{l}79(53.7 \%) \\
68(46.3 \%)\end{array}$ \\
\hline $\begin{array}{c}\text { Received all the } \\
\text { basic vaccinations }\end{array}$ & $\begin{array}{l}\text { Yes } \\
\text { No }\end{array}$ & $\begin{array}{c}146(99.3 \%) \\
1(0.7 \%)\end{array}$ \\
\hline $\begin{array}{c}\text { Pediatrician } \\
\text { consultation during } \\
\text { the last year }\end{array}$ & $\begin{array}{l}\text { Never } \\
1-2 \text { times } \\
\text { More than } 2\end{array}$ & $\begin{array}{l}18(12.2 \%) \\
64(43.6 \%) \\
65(44.2 \%)\end{array}$ \\
\hline $\begin{array}{l}\text { Private } \\
\text { pediatrician } \\
\text { consultation during } \\
\text { the last year }\end{array}$ & $\begin{array}{l}\text { Never } \\
1-2 \text { times } \\
\text { More than } 2\end{array}$ & $\begin{array}{c}108(73.5 \%) \\
31(21.0 \%) \\
8(5.5 \%)\end{array}$ \\
\hline $\begin{array}{l}\text { Prescribed drugs } \\
\text { use }\end{array}$ & $\begin{array}{l}\text { Never } \\
1-4 \text { times } \\
\text { More than } 4\end{array}$ & $\begin{array}{l}26(17.7 \%) \\
84(57.1 \%) \\
37(25.2 \%)\end{array}$ \\
\hline $\begin{array}{l}\text { Parent chosen } \\
\text { drugs use }\end{array}$ & $\begin{array}{l}\text { Never } \\
1-4 \text { times } \\
\text { More than } 4\end{array}$ & $\begin{array}{c}103(70.0 \%) \\
37(25.2 \%) \\
7(4.8 \%)\end{array}$ \\
\hline $\begin{array}{l}\text { Drugs suggest by } \\
\text { other use }\end{array}$ & $\begin{array}{l}\text { Never } \\
1-2 \text { times } \\
\text { More than } 2\end{array}$ & $\begin{array}{c}95(64.6 \%) \\
38(25.9 \%) \\
14(9.5 \%)\end{array}$ \\
\hline
\end{tabular}

Table 1. Baseline characteristics of the children 


\begin{tabular}{|c|c|c|c|}
\hline \multicolumn{2}{|c|}{$\begin{array}{l}\text { CAM-users and not CAM-users groups } \\
\text { characteristics }\end{array}$} & \multirow{2}{*}{$\begin{array}{l}\text { CAM use }(\mathrm{n}=71) \text {, } \\
\mathrm{N}(\%) \\
6.97\end{array}$} & \multirow{2}{*}{$\begin{array}{l}\text { CAM not use }(n=76) \text {, } \\
\mathrm{N}(\%)\end{array}$} \\
\hline Age & Mean (?), years & & \\
\hline Sex & $\begin{array}{l}\text { Female } \\
\text { Male }\end{array}$ & $\begin{array}{l}40(54.8 \%) \\
31(41,9 \%)\end{array}$ & $\begin{array}{l}33(45.2 \%) \\
43(58,1 \%)\end{array}$ \\
\hline $\begin{array}{l}\text { Episodes of sickness in } \\
\text { the last year }\end{array}$ & $\begin{array}{l}0 \\
\text { Less than } 6 \\
6 \text { or more }\end{array}$ & $\begin{array}{l}5(31.3 \%) \\
54(48.6 \%) \\
12(60.0 \%)\end{array}$ & $\begin{array}{l}11(68.7 \%) \\
57(51.4 \%) \\
8(40.0 \%)\end{array}$ \\
\hline Main pathologies & $\begin{array}{l}\text { ENT patologies } \\
\text { Other patologies }\end{array}$ & $\begin{array}{l}45(57.0 \%) \\
26(38.2 \%)\end{array}$ & $\begin{array}{l}34(43.0 \%) \\
42(61.8 \%)\end{array}$ \\
\hline $\begin{array}{l}\text { Received all the basic } \\
\text { vaccinations }\end{array}$ & $\begin{array}{l}\text { Yes } \\
\text { No }\end{array}$ & $\begin{array}{l}70(47.9 \%) \\
1(100 \%)\end{array}$ & $\begin{array}{l}76(52.1 \%) \\
0\end{array}$ \\
\hline $\begin{array}{l}\text { Pediatrician consultation } \\
\text { during the last year }\end{array}$ & $\begin{array}{l}\text { Never } \\
1-2 \text { times } \\
\text { More than } 2\end{array}$ & $\begin{array}{l}8(44.4 \%) \\
31(48.4 \%) \\
32(49.2 \%)\end{array}$ & $\begin{array}{l}10(55.6 \%) \\
33(51.6 \%) \\
33(50.8 \%)\end{array}$ \\
\hline $\begin{array}{l}\text { Private pediatrician } \\
\text { consultation during the } \\
\text { last year }\end{array}$ & $\begin{array}{l}\text { Never } \\
1-2 \text { times } \\
\text { More than } 2\end{array}$ & $\begin{array}{l}53(49.0 \%) \\
16(51.6 \%) \\
2(25.0 \%)\end{array}$ & $\begin{array}{l}55(51.0 \%) \\
15(48.4 \%) \\
6(75 \%)\end{array}$ \\
\hline $\begin{array}{l}\text { Prescripeted drugs use } \\
\text { in the last year }\end{array}$ & $\begin{array}{l}\text { Never } \\
1-4 \text { times } \\
\text { More than } 4\end{array}$ & $\begin{array}{ll}11 & (42.3 \%) \\
37 & (44.0 \%) \\
23 & (62.2 \%)\end{array}$ & $\begin{array}{ll}15 & (57.7 \%) \\
47 & (56.0 \%) \\
14 & (37.8 \%)\end{array}$ \\
\hline Parent chosen drug use & $\begin{array}{l}\text { Never } \\
1-4 \text { times } \\
\text { More than } 4\end{array}$ & $\begin{array}{l}44(42.7 \%) \\
22(59.5 \%) \\
5(71.4 \%)\end{array}$ & $\mid \begin{array}{l}59(57.3 \%) \\
15(40.5 \%) \\
2(28.6 \%)\end{array}$ \\
\hline
\end{tabular}




\begin{tabular}{|c|c|c|c|}
\hline $\begin{array}{l}\text { Drug suggest by other } \\
\text { use }\end{array}$ & $\mid \begin{array}{l}\text { Never } \\
1-2 \text { times } \\
\text { More than } 2\end{array}$ & $\begin{array}{l}35(36.8 \%) \\
25(65.8 \%) \\
11(78.6 \%)\end{array}$ & $\begin{array}{ll}60 & (63.2 \%) \\
13 & (34.2 \%) \\
3 & (21.4 \%)\end{array}$ \\
\hline
\end{tabular}

Table 2. CAM-users and not CAM-users groups characteristics

\begin{tabular}{|c|c|c|c|}
\hline \multicolumn{2}{|c|}{ Parents' characteristics } & \multirow{2}{*}{$\begin{array}{c}\text { CAM user }(n=71) \text {, } \\
\mathrm{N}(\%) \\
55(52.9 \%)\end{array}$} & \multirow{2}{*}{$\begin{array}{c}\text { CAM not user } \\
(\mathrm{n}=76), \\
\text { N (\%) } \\
49(47.1 \%)\end{array}$} \\
\hline Parents interviewed & Mother & & \\
\hline \multirow[t]{2}{*}{ Education level } & $\begin{array}{l}\text { Mother } \\
\text { - Secondary school } \\
\text { - High school } \\
\text { - University }\end{array}$ & $\begin{array}{l}13(39.4 \%) \\
33(49.3 \%) \\
25(53.2 \%)\end{array}$ & $\begin{array}{l}20(60.0 \%) \\
34(50.7 \%) \\
22(46.8 \%)\end{array}$ \\
\hline & $\begin{array}{l}\text { Father } \\
\text { - Secondary school } \\
\text { - High school } \\
\text { - University }\end{array}$ & $\begin{array}{l}27(44.3 \%) \\
27(48.2 \%) \\
17(56.7 \%)\end{array}$ & $\begin{array}{l}34(55.7 \%) \\
29(51.8 \%) \\
13(43.3 \%)\end{array}$ \\
\hline \multirow[t]{2}{*}{ Occupation status } & $\begin{array}{l}\text { Mother } \\
\text { - Unemployed } \\
\text { - Employed } \\
\text { - Housewife }\end{array}$ & $\begin{array}{l}12(32.4 \%) \\
5(45.4 \%) \\
54(54.5 \%)\end{array}$ & $\begin{array}{c}25(67.6 \%) \\
6(54.6 \%) \\
45(45.5 \%)\end{array}$ \\
\hline & Father & & \\
\hline
\end{tabular}




\begin{tabular}{|l|l|c|c|}
\hline & - Unemployed & $3(27.3 \%)$ & $8(72.7 \%)$ \\
& - Employed & $68(50.7 \%)$ & $66(48.3 \%)$ \\
- Retired & 0 & $2(100 \%)$ \\
\hline $\begin{array}{l}\text { Vaccination } \\
\text { propensity }\end{array}$ & Yes & $50(42.1 \%)$ & $66(56.9 \%)$ \\
& Not always & $11(57.9 \%)$ & $8(42.1 \%)$ \\
& No & $9(90.0 \%)$ & $1(10.0 \%)$ \\
\hline
\end{tabular}

Table 3. Mothers' and fathers' characteristics according to CAM use

\begin{tabular}{|l|l|l|l|l|l|l|}
\hline & \multicolumn{3}{l}{ Univariable analysis } & \multicolumn{3}{l}{ Multivariable analysis } \\
\hline Parameters & OR & $95 \%$ CI & P value & OR & $95 \%$ CI & P value \\
\hline $\begin{array}{l}\text { Child age in } \\
\text { years }\end{array}$ & 0.908 & $0.821-1.003$ & 0.058 & 0.919 & $0.813-1.039$ & 0.176 \\
\hline $\begin{array}{l}\text { Accesses to } \\
\text { paediatrician }\end{array}$ & 1.048 & $0.960-1.144$ & 0.292 & 1.022 & $0.925-1.130$ & 0.664 \\
\hline ENT disease & 2.138 & $1.103-4.142$ & 0.024 & 1.477 & $0.685-3.184$ & 0.32 \\
\hline Female sex & 1.681 & $0.876-3.229$ & 0.119 & 1.531 & $0.736-3.184$ & 0.254 \\
\hline $\begin{array}{l}\text { Positive } \\
\text { attitude } \\
\text { towards } \\
\text { vaccination }\end{array}$ & 0.341 & $0.143-0.812$ & 0.015 & 0.398 & $0.154-1.032$ & 0.058 \\
\hline $\begin{array}{l}\text { Use of } \\
\text { treatments } \\
\text { suggested } \\
\text { by others }\end{array}$ & 1.743 & $1.236-2.457$ & 0.002 & 1.664 & $1.162-2.382$ & 0.005 \\
\hline \begin{tabular}{l} 
SES status \\
\hline
\end{tabular} & 1.282 & $0.806-2.039$ & 0.295 & 1.172 & $0.695-1.977$ & 0.552 \\
\hline
\end{tabular}

Table 4. Univariable and multivariable analysis 


\begin{tabular}{|c|c|c|}
\hline \multicolumn{2}{|l|}{ CAM use modalities } & \multirow{2}{*}{$\begin{array}{l}\mathrm{N}(\%) \\
41(73.2 \%) \\
23(41.1 \%)\end{array}$} \\
\hline CAM type & $\begin{array}{l}\text { Herbal medicine } \\
\text { Homeopaty }\end{array}$ & \\
\hline Type of use of last year & $\begin{array}{l}\text { Occasional use (once) } \\
\text { Frequent use (2-5 times) } \\
\text { Regular use }(>7)\end{array}$ & $\begin{array}{ll}16 & (28.6 \%) \\
28 & (50.0 \%) \\
12 & (21.4 \%)\end{array}$ \\
\hline Type of pathologies treated & $\begin{array}{l}\text { ENT } \\
\text { Neuropsichiatric } \\
\text { Immunity empowerment } \\
\text { Gastrointestinal } \\
\text { Others }\end{array}$ & $\begin{array}{l}58(81.7 \%) \\
4(5.6 \%) \\
19(26.8 \%) \\
4(5.6 \%) \\
3(4.2 \%)\end{array}$ \\
\hline Level of satisfaction & $\begin{array}{l}\text { Not answered } \\
\text { Never } \\
\text { Almost always } \\
\text { Sometimes }\end{array}$ & $\begin{array}{ll}2 & (2.8 \%) \\
14 & (19.7 \%) \\
42 & (59.2 \%) \\
13 & (18.3 \%)\end{array}$ \\
\hline $\begin{array}{l}\text { Association with conventional } \\
\text { medicine }\end{array}$ & $\begin{array}{l}\text { Only alternative medicine } \\
\text { Associated with conventional }\end{array}$ & $\begin{array}{l}42(59.2 \%) \\
29(40.8 \%)\end{array}$ \\
\hline $\begin{array}{l}\text { Which medicine is more } \\
\text { effective? }\end{array}$ & $\begin{array}{l}\text { Not answered } \\
\text { Alternative medicines } \\
\text { Conventional medicine }\end{array}$ & $\begin{array}{l}17(23.9 \%) \\
9(12.7 \%) \\
45(63.4 \%)\end{array}$ \\
\hline What do you do in case of CAM & Not answered & $5(7.0 \%)$ \\
\hline
\end{tabular}




\begin{tabular}{|c|c|c|}
\hline inefficacy & $\begin{array}{l}\text { Would try again with CAM } \\
\text { Would switch to conventional } \\
\text { medicine }\end{array}$ & $\begin{array}{l}10(14.1 \%) \\
56(78.9 \%)\end{array}$ \\
\hline $\begin{array}{l}\text { Do you think medical } \\
\text { prescription is necessary? }\end{array}$ & $\begin{array}{l}\text { It depends on the pathology } \\
\text { No } \\
\text { Yes, always }\end{array}$ & $\begin{array}{l}15(21.1 \%) \\
9(12.7 \%) \\
47(66.2 \%)\end{array}$ \\
\hline $\begin{array}{l}\text { Do you think CAM has } \\
\text { collateral effects }\end{array}$ & $\begin{array}{l}\text { No } \\
\text { Yes }\end{array}$ & $\begin{array}{l}68(95.8 \%) \\
3(4.2 \%)\end{array}$ \\
\hline Will you use CAM in the future & $\begin{array}{l}\text { No } \\
\text { Don’t know } \\
\text { Yes }\end{array}$ & $\begin{array}{ll}7 & (9.9 \%) \\
3 & (4.2 \%) \\
61 & (85.9 \%)\end{array}$ \\
\hline Motivations to CAM use & $\begin{array}{l}\text { Collateral effects } \\
\text { Prescribed by doctors } \\
\text { Already used by parents } \\
\text { Prevent antibiotic resistance } \\
\text { Suggested by pharmacists } \\
\text { Others }\end{array}$ & $\begin{array}{ll}29 & (40.8 \%) \\
21 & (29.6 \%) \\
6 & (8.5 \%) \\
5 & (7.0 \%) \\
3 & (4.2 \%) \\
10 & (14.1 \%)\end{array}$ \\
\hline Most used remedies & $\begin{array}{l}\text { Snail drool syrup } \\
\text { Oscillococcinum }\end{array}$ & $\begin{array}{l}14(19.7 \%) \\
10(14.1 \%)\end{array}$ \\
\hline
\end{tabular}

Table 5. CAM use modalities

\begin{tabular}{|c|c|c|}
\hline \multicolumn{2}{|c|}{ Pediatricians CAM propension } & $\mathrm{N}(\%)$ \\
\hline $\begin{array}{l}\text { Does not prescribe } \\
\text { CAM }\end{array}$ & No & $5(18,5 \%)$ \\
\hline $\begin{array}{l}\text { Of those who } \\
\text { do not } \\
\text { prescribe } \\
(\mathrm{N}=5)\end{array}$ & $\begin{array}{l}\text { Because considered } \\
\text { uneffective }\end{array}$ & $3 / 5(60 \%)$ \\
\hline Prescribes CAM & Yes & $22(81,5 \%)$ \\
\hline $\begin{array}{l}\text { CAM type } \\
\text { Of those who } \\
\text { prescribe } \\
(\mathrm{N}=22)\end{array}$ & $\begin{array}{l}\text { Herbal medicine } \\
\text { Homeopathy } \\
\text { Osteopathy } \\
\text { Acopuncture } \\
\text { Mesoterapy } \\
\text { Homotoxicology }\end{array}$ & $\begin{array}{ll}22 & (100 \%) \\
9 & (40,9 \%) \\
6 & (27,3 \%) \\
1 & (4,5 \%) \\
1 & (4,5 \%) \\
1 & (4,5 \%)\end{array}$ \\
\hline
\end{tabular}




\begin{tabular}{|l|l|l|}
$\begin{array}{l}\text { Association with } \\
\text { conventional } \\
\text { medicine }\end{array}$ & $\begin{array}{l}\text { Yes } \\
\text { No }\end{array}$ & $\begin{array}{l}20(90,9 \%) \\
2(9,1 \%)\end{array}$ \\
\hline Trained about CAM & $\begin{array}{l}\text { No } \\
\text { Yes }\end{array}$ & $\begin{array}{l}19(86,9 \%) \\
3(13,1 \%)\end{array}$ \\
$\begin{array}{l}\text { Average number of } \\
\text { Cam prescription per } \\
\text { week }\end{array}$ & 5,1 & $\begin{array}{l}\text { Min-max }(1- \\
20)\end{array}$ \\
\hline
\end{tabular}

Table 6. Family pediatrician's survey results 